\title{
Application of Natural Deep Eutectic Solvent-Based Ultrasonic Assisted Extraction of Total Polyphenolic and Caffeine Content from Coffe Beans (Coffea Beans L.) For Instant Food Products
}

\author{
Islamudin Ahmad ${ }^{1}$, Adela Surya Pertiwi ${ }^{2}$, Yulietta Heryani Kembaren², Arif Rahman², Abdul Mun'im²* \\ ${ }^{1}$ Department of Pharmaceutical Sciences, Faculty of Pharmacy, Mulawarman University, Kampus UNMUL Samarinda 75119, East Kalimantan, Indonesia. \\ ${ }^{2}$ Department of Pharmaceutical Sciences, Faculty of Pharmacy, Universitas Indonesia, Kampus UI Depok 16424, West Java, Indonesia.
}

\begin{tabular}{|c|c|}
\hline ARTICLE INFO & ABSTRACT \\
\hline Artic & \multirow{5}{*}{$\begin{array}{l}\text { This study aims to determine and obtain the total polyphenolic and caffeine content from coffee beans (Coffea arabica } \\
\text { L.) with some combination of factors. The extraction process was performed using natural deep eutectic solvent-based } \\
\text { ultrasonic-assisted extraction (NADES-UAE) method with the different condition including extraction time, NADES } \\
\text { ratio, and liquid-solid ratio. The total polyphenolic content was calculated using a microplate reader } 96 \text { well. The } \\
\text { caffeine content was examined using high-performance liquid chromatography. Based on the results demonstrated the } \\
\text { effect of different NADES components (namely lactic acid-sucrose and citric acid-glucose) on the total polyphenolic } \\
\text { and caffeine content. The highest total polyphenolic content was } 87.01 \mathrm{mg} \mathrm{GAE} / \mathrm{g} \text { sample }(2 \mathrm{~g} / \mathrm{g} \text { lactic acid-sucrose } \\
\text { ratio and } 10 \mathrm{~mL} / \mathrm{g} \text { liquid-solid ratio for } 15 \text { minutes) and } 62.91 \mathrm{mg} \mathrm{GAE} / \mathrm{g} \text { sample }(5 \mathrm{~g} / \mathrm{g} \text { citric acid-glucose ratio and } \\
15 \mathrm{~mL} / \mathrm{g} \text { liquid-solid ratio for } 15 \text { minutes). Whereas, the highest caffeine content was } 4.45 \mathrm{mg} / \mathrm{g} \text { ( } 4 \mathrm{~g} / \mathrm{g} \text { lactic acid- } \\
\text { sucrose and } 15 \mathrm{~mL} / \mathrm{g} \text { liquid-solid ratio for } 35 \text { minutes) and } 1.30 \mathrm{mg} / \mathrm{g}(2 \mathrm{~g} / \mathrm{g} \text { lactic acid-sucrose and } 30 \mathrm{~mL} / \mathrm{g} \text { liquid- } \\
\text { solid ratio for } 5 \mathrm{minutes),} \mathrm{respectively.} \mathrm{These} \mathrm{results} \mathrm{were} \mathrm{obtained} \mathrm{from} \mathrm{the} \mathrm{green} \mathrm{extraction} \mathrm{method} \mathrm{with} \mathrm{rapid,} \mathrm{easy,} \\
\text { inexpensive, and environmentally friendly. }\end{array}$} \\
\hline $09 / 05 / 2018$ & \\
\hline A & \\
\hline Available online & \\
\hline $\begin{array}{l}\text { Key words: } \\
\text { Caffeine content, Coffea } \\
\text { arabica L, natural deep } \\
\text { eutectic solvent, total } \\
\text { polyphenolic content, } \\
\text { ultrasonic-assisted } \\
\text { extraction. }\end{array}$ & \\
\hline
\end{tabular}

\section{INTRODUCTION}

Indonesia is one of the largest coffee producer countries in the world (Rahardjo, 2012). Coffee beans sold in the world market is usually a combination of two types of plants consisting of arabica and robusta (Rahardjo, 2012). The difference between both species mainly in the taste and level of caffeine content. Arabica coffee tends to be more expensive, softer, and lower caffeine levels compared to robusta types (Njoroge et al., 2005).

Coffee beans (Coffea arabica L.) was used as a sample, and these species contain rich a polyphenolic compound mainly chlorogenic acid (Amorim et al., 2009; Baeza et al., 2016). Polyphenolic compounds in coffee beans have efficacy as weight loss with the modulation of glucose metabolism in humans body

"Corresponding Author

Abdul Mun'im, Building A, 3rd Floor, Rumpun Ilmu Kesehatan, Kampus UI Depok, West Java, Indonesia. E-mail: abdul.munim61@ui.ac.id
(Kozuma et al., 2005; Blum et al., 2007), it also has activity as antihypertension (Watanabe et al., 2006). Coffee is also famous for its caffeine content (Zhang et al., 2013). Caffeine is a derivative of the xanthine alkaloids present in coffee and has a stimulating effect on the body (Xia et al., 2015). To be utilized more widely in the health field mainly for treatment, secondary metabolite compounds (especially polyphenols and caffeine groups) need to be separated using the appropriate extraction method. To extract polyphenols and caffeine from coffee beans requires the right solvent for the target compound to be optimally separated.

The application of green chemistry principles to the extraction of target secondary metabolite from plants continues to rise (Kerton, 2009). The use of a natural deep eutectic solvent (NADES) is one of the principles of green chemistry, the selection of the right solution is crucial to success in the extraction process (Kerton, 2009; Dai et al., 2016). From the standpoint of biochemical and pharmaceutical study, the development of new and green methods for the extraction of bioactive compounds 
from a natural product is essential (Chemat and Vian, 2014). NADES has some advantages over conventional solvents that are inexpensive, environmentally friendly, and food grade, so it is safe to consume (Dai et al., 2015). The use of NADES as a green solvent is expected that the obtained extracts are directly used to prepare the finished product and are not directed to the isolation and purification of the compound. In this process can be applied with the desired finished product is granule or instant granule and another type of food product. In addition, NADES has also been recognized as a new class as a sustainable solvent as it is made up of widely available, natural, non-toxic and biodegradable components (Fernández et al., 2017; Pan et al., 2017). Some studies has been reported that the use of NADES as a green solvent combined with nonconventional extraction methods (including ultrasonic, microwave, supercritical, and other) to extract the target secondary metabolite such as baicalin (Wang et al., 2018), flavonoid (Wei et al., 2015), phenolic (Wei et al., 2015; Fernández et al., 2017), holo-cellulose, $\alpha$-cellulose, acid-insoluble-lignin (Pan et al., 2017), anthocyanins (Dai et al., 2016), and so on. However, extraction of polyphenolic and caffeine content from coffee beans has not been reported.

In this study, the extraction of polyphenolic and caffeine content from coffee beans was performed using NADES consisting of lactic acid-sucrose and citric acid-glucose components combined with ultrasonic-assisted extraction (NADES-UAE) method based on the parameter factors of extraction condition. This study aims to determine and obtain the total of polyphenolic and caffeine content with some combination factors of extraction conditions such as extraction time, NADES ratio, and liquid-solid ratio.

\section{MATERIALS AND METHODS}

\section{Materials}

The sample of coffee beans was obtained from Gayo Coffee shop at Takengon, Central Aceh, Indonesia. Caffeine standard was purchased from CSPC, China. Citric acid, lactic acid, sucrose, glucose, and aqua demineralization were purchased from Brataco, Indonesia. Methanol HPLC grade was obtained from PT. Merck, Germany (via PT. Elo Karsa Utama, Indonesia). Gallic acid standard, Folin-Ciocalteu reagent, and sodium carbonate were purchased from Sigma-Aldrich, USA (via PT. Elo Karsa Utama, Indonesia).

\section{Equipment}

The equipment was used in this study, such as ultrasonic bath type (Krisbow) modified for as ultrasonic assisted extraction, microplate reader 96 well spectrophotometer UV-VIS (VersaMax $^{\mathrm{TM}}$ ELISA Microplate Reader, USA), micropipette 10-100 and 100-1000 $\mu \mathrm{L}$ (Thermo Scientific, USA), vortex mixer (WiseMix), centrifuge (Labsco, USA), high performance liquid chromatography (Shimadzu, Japan), column $\mathrm{C}_{18} 4.6 \mathrm{~mm} \times 150$ $\mathrm{mm}, 5 \mu \mathrm{m}$ (Shimpack), $\mathrm{pH}$ meter (Eutech Instrument).

\section{Preparation of Natural Deep Eutectic (NADES) solvent}

In this study, NADES was used include lactic acidsucrose with ratio $4: 1,5: 1$, and $6: 1 \mathrm{~g} / \mathrm{g}$ and citric acid-glucose with ratio $1: 1,2: 1$, and $3: 1 \mathrm{~g} / \mathrm{g}$, respectively. The NADES components were weighed according to the predefined ratio and were added aqua demineralization, then was stirred using hotplate stirrer and then filtered to obtain a homogeneous solution (Dai, van Spreonsen et al., 2013; Dai, Witkamp et al., 2013).

\section{Extraction process}

A natural deep eutectic solvent-based ultrasonicassisted extraction (NADES-UAE) method was applied to extract polyphenolic and caffeine content based on the literature (Wei et al., 2015; Dai et al., 2016). Briefly, the dried powder of coffee beans (1 gram) was mixed with NADES solution. The mixture solution was vortexed then extracted using NADES-UAE method which some combinations factor of extraction condition. After the extraction process, the extract solution and residue were separated using Buchner funnel. The extract solution was stored at room temperature and until ready to use.

\section{Determination of total polyphenolic content}

The total polyphenolic content determination was conducted by microplate reader 96 well method according to previous studies (Bobo-García et al., 2014; Ahmad et al., 2017a; Ahmad et al., 2017b). Briefly, the extract or standard solution $(20 \mu \mathrm{L})$ was added to $100 \mu \mathrm{L}$ of $25 \%$ Folin-Ciocalteu reagent, homogenized and allowed for 4-6 minutes. Then sodium carbonate solution $(75 \mu \mathrm{L})$ was added, homogenized and incubated for 2 hours at room temperature in the dark. The measurement of absorbance was performed using microplate reader 96 spectrophotometer UV-VIS (VersaMax ${ }^{\mathrm{TM}}$, USA) at a $750 \mathrm{~nm}$ wavelength. Gallic acid with concentrations from 12.5 to $200 \mu \mathrm{g} / \mathrm{mL}$ were used as a standard (Ahmad et al., 2017a) and the regression formula was $Y=0.0158 X+0.2064$ with $R=0.9969$, where $Y$ is concentration and $X$ is absorbance. The equation was used to determine the TPC from each extract.

\section{Determination of caffeine content}

Determination of caffeine content was performed using high-performance liquid chromatography (HPLC) based on the study has been reported by (Ali et al., 2012), with modification. The HPLC separation was performed using column $\mathrm{C}_{18} 4.6 \mathrm{~mm}$ $\times 150 \mathrm{~mm}, 5 \mu \mathrm{m}$ (Shimpack), methanol: aqua demineralization (30:70) of the mobile phase, and detector UV-Vis at $270 \mathrm{~nm}$. The sample injection of extract or standard solution was set at $20 \mu \mathrm{L}$ with a flow rate of $1.3 \mathrm{~mL} /$ minutes. The retention time of caffeine was used as a standard based on peak area of chromatogram with some different concentration include $0.2,0.4,0.8,1$, and $1.2 \mu \mathrm{g} / \mathrm{mL}$, respectively. The equation formula was obtained $Y=$ $63537 X+36507$ with $R=0.99993$ and was applied to calculate the caffeine content in each extract, where $Y$ is concentration and $X$ is peak area.

\section{RESULTS AND DISCUSSION}

\section{Extraction process}

In this study, the development of extraction process based on the approach of green chemistry principles to obtain an efficiency of extraction conditions with the optimum yields of secondary target metabolite from the matrix sample. Extraction condition refers to the research that has been reported by (García et al., 2016; Fernández et al., 2017). Combination factors of 
extraction condition were used in this study including NADES ratio, liquid-solid ratio, and extraction time. Extraction of coffee beans was performed using NADES with lactic acid-sucrose and citric acid-glucose compositions combined with ultrasonicassisted extraction (NADES-UAE) and controlled temperature at $40^{\circ} \mathrm{C}$ to prevent degradation of compounds, mainly polyphenolic content (Wei et al., 2015; Wei et al., 2015; Fernández et al., 2017).

In the present study, extraction of secondary metabolite (mainly polyphenolic and caffeine content) from green coffee beans was performed using NADES-UAE method. The selection of extraction method was based on the time efficiency, the amount of solvent used, the increase of surface area of the sample, the cost efficiency, and prevent the degradation of the various compounds. This method was chosen because of its rapid and comfortable for use, inexpensive, environmentally friendly, and available in the laboratory. Also, the process is suitable for the extraction of polyphenolic compounds that are vulnerable to oxidization when exposed to high light and temperature and may also increase the yield of secondary metabolite. Sonication is the production of sound waves that create a cavitation wavelength near the sample tissue, which disrupts the cell wall of the plant so that it releases the compounds contained in the cells (Xu et al., 2015; Pham et al., 2017). The efficiency of extraction using ultrasonic-assisted extraction method was influenced by time, power, and temperature (Bubalo et al., 2016; Fernández et al., 2017).

Some factors must be considered in the extraction process using the UAE method, i.e., extraction time, solvent combination ratio, power irradiation, extraction temperature, and samplesolvent ratio. In this study, the extraction process was conducted using 3 factors and 3 levels (including low, medium, and high) with 27 total combinations of extraction condition against total polyphenol and caffeine content. The parameter factors consisted of NADES ratio, the liquid-solid ratio, and extraction time, as can be seen in Table 1 .

Table 1: Experimental design according to the combination of extraction condition factor using natural deep eutectic solvent based ultrasonic-assisted extraction (NADES-UAE)

\begin{tabular}{|c|c|c|c|c|c|c|c|c|}
\hline \multirow{2}{*}{ No. } & \multirow{2}{*}{ Parameters factor } & \multirow{2}{*}{ Unit } & \multicolumn{3}{|c|}{ Lactic acid - sucrose } & \multicolumn{3}{|c|}{ Citric acid - glucose } \\
\hline & & & Low & Medium & High & Low & Medium & High \\
\hline 1 & NADES ratio & $\mathrm{g} / \mathrm{g}$ & 4 & 5 & 6 & 1 & 2 & 3 \\
\hline 2 & Liquid-Solid Ratio & $\mathrm{mL} / \mathrm{g}$ & 15 & 45 & 75 & 10 & 20 & 30 \\
\hline 3 & Extraction Time & Minutes & 15 & 35 & 60 & 5 & 10 & 15 \\
\hline
\end{tabular}

Table 2: Results of 10 highest total polyphenolic content of coffee beans extract obtained using lactic acid-sucrose as a solvent.

\begin{tabular}{|c|c|c|c|c|}
\hline No. & $\begin{array}{c}\text { Factor A: } \\
\text { Lactic acid-sucrose ratio (g/g) }\end{array}$ & $\begin{array}{c}\text { Factor B: } \\
\text { Liquid-solid ratio }(\mathrm{mL} / \mathrm{g})\end{array}$ & $\begin{array}{c}\text { Factor C: } \\
\text { Extraction time (Minutes) }\end{array}$ & $\begin{array}{l}\text { Response: } \\
\text { Total polyphenolic content (mg GAE/g) }\end{array}$ \\
\hline 1 & 2 & 10 & 15 & 87.01 \\
\hline 2 & 1 & 20 & 15 & 84.43 \\
\hline 3 & 3 & 20 & 15 & 68.73 \\
\hline 4 & 2 & 20 & 10 & 64.54 \\
\hline 5 & 2 & 30 & 5 & 64.50 \\
\hline 6 & 1 & 20 & 5 & 63.57 \\
\hline 7 & 2 & 30 & 15 & 62.41 \\
\hline 8 & 3 & 10 & 10 & 56.48 \\
\hline 9 & 3 & 20 & 5 & 56.23 \\
\hline 10 & 2 & 10 & 5 & 53.69 \\
\hline
\end{tabular}

Lactic acid-sucrose (with a ratio of $1: 1,2: 1$, and $3: 1 \mathrm{~g} / \mathrm{g}$ ) and citric acid-glucose $(4: 1,5: 1$, dan $6: 1 \mathrm{~g} / \mathrm{g}$ ratio) were selected as the following component of NADES. Then was added with aqua demineralization that aims to reduce viscosity and accelerate NADES preparation. Lactic acid and citric acid act as hydrogen bond acceptor (HBA), while sucrose and glucose act as hydrogen bond donor (HBD) (Lu et al., 2016; Fernández et al., 2017; Wang et al., 2018).

\section{Total polyphenolic content determination}

Table 2 and Table 3, shows the use effect of NADES as a solvent (lactic acid-sucrose and citric acid-glucose) with NADESUAE method based on a combination of extraction condition against total polyphenolic content. Based on the results in Table 2 was achieved the 10 highest of total polyphenolic content using some combination factor of extraction condition and the best value of $87.01 \mathrm{mg} \mathrm{GAE} / \mathrm{g}$ sample with $2 \mathrm{~g} / \mathrm{g}$ of lactic acid-sucrose ratio and $10 \mathrm{~g} / \mathrm{mL}$ of the liquid-solid ratio for 15 minutes. While, in Table 3 was obtained the 10 highest of total polyphenolic content using some combination factor of extraction condition and the best value of $62.91 \mathrm{mg} \mathrm{GAE} / \mathrm{g}$ sample using $5 \mathrm{~g} / \mathrm{g}$ of citric acidglucose ratio and $15 \mathrm{~mL} / \mathrm{g}$ of the liquid-solid ratio for 15 minutes of extraction time.

The highest total polyphenolic content of $87.01 \mathrm{mg}$ GAE/g sample were obtained using NADES with components of a combination of lactic acid and sucrose $(2: 1 \mathrm{~g} / \mathrm{g})$, the liquid-solid ratio of $10 \mathrm{~mL}$, and extraction time of 5 minutes. The result has a higher total polyphenolic content than the study has been reported by (Hečimović et al., 2011) with TPC of $33.12 \mathrm{mg} \mathrm{GAE} / \mathrm{g}$ sample from coffee beans based on the degree of roasting. And on the other hand, the study has been reported by (Xu et al., 2015) that the extraction using the optimum condition of the subcritical water 
extraction (SWE) method has approximately the same level of $86.23 \mathrm{mg} \mathrm{GAE} / \mathrm{g}$ sample. The use of lactic acid and sucrose as a component of NADES is higher than the use of citric acid and glucose with the highest total polyphenolic content of $62.91 \mathrm{mg}$ GAE/g sample.

Table 3: Results of 10 highest total polyphenolic content of coffee beans extract obtained using citric acid-glucose as a solvent.

\begin{tabular}{|c|c|c|c|c|}
\hline No. & $\begin{array}{l}\text { Factor A: } \\
\text { Citric acid-glucose ratio (g/g) }\end{array}$ & $\begin{array}{c}\text { Factor B: } \\
\text { Liquid-solid ratio }(\mathrm{mL} / \mathrm{g})\end{array}$ & $\begin{array}{c}\text { Factor C: } \\
\text { Extraction time (Minutes) }\end{array}$ & $\begin{array}{l}\text { Response: } \\
\text { Total polyphenolic content (mg GAE/g) }\end{array}$ \\
\hline 1 & 5 & 15 & 15 & 62.91 \\
\hline 2 & 5 & 15 & 60 & 61.86 \\
\hline 3 & 6 & 15 & 35 & 49.09 \\
\hline 4 & 4 & 15 & 35 & 64.54 \\
\hline 5 & 4 & 45 & 15 & 30.27 \\
\hline 6 & 4 & 45 & 60 & 29.34 \\
\hline 7 & 6 & 45 & 60 & 28.26 \\
\hline 8 & 6 & 45 & 35 & 27.75 \\
\hline 9 & 6 & 45 & 15 & 24.10 \\
\hline 10 & 5 & 75 & 15 & 22.46 \\
\hline
\end{tabular}

Table 4: Results of the 10 highest caffeine content of coffee beans extract obtained using lactic acid-sucrose as a solvent.

\begin{tabular}{|c|c|c|c|c|}
\hline No. & $\begin{array}{c}\text { Factor A: } \\
\text { Lactic acid-sucrose ratio }(\mathrm{g} / \mathrm{g})\end{array}$ & $\begin{array}{c}\text { Factor B: } \\
\text { Liquid-solid ratio }(\mathrm{mL} / \mathrm{g})\end{array}$ & $\begin{array}{c}\text { Factor 3: } \\
\text { Extraction time (Minutes) }\end{array}$ & $\begin{array}{c}\text { Response: } \\
\text { Caffeine content }(\mathrm{mg} / \mathrm{g})\end{array}$ \\
\hline 1 & 2 & 30 & 5 & 1.30 \\
\hline 2 & 2 & 30 & 15 & 0.73 \\
\hline 3 & 3 & 20 & 15 & 0.69 \\
\hline 4 & 2 & 20 & 10 & 0.66 \\
\hline 5 & 1 & 30 & 10 & 0.62 \\
\hline 6 & 3 & 20 & 5 & 0.61 \\
\hline 7 & 1 & 20 & 15 & 0.58 \\
\hline 8 & 3 & 30 & 10 & 0.52 \\
\hline 9 & 2 & 10 & 5 & 0.48 \\
\hline 10 & 3 & 10 & 10 & 0.48 \\
\hline
\end{tabular}

Table 5: Results of the 10 highest caffeine content of coffee beans extract obtained using citric acid-glucose as a solvent.

\begin{tabular}{|c|c|c|c|c|}
\hline No. & $\begin{array}{c}\text { Factor A: } \\
\text { Citric acid - glucose ratio }(\mathrm{g} / \mathrm{g})\end{array}$ & $\begin{array}{c}\text { Factor B: } \\
\text { Liquid-solid ratio }(\mathrm{mL} / \mathrm{g})\end{array}$ & $\begin{array}{c}\text { Factor 3: } \\
\text { Extraction time (Minutes) }\end{array}$ & $\begin{array}{c}\text { Response: } \\
\text { Caffeine content }(\mathrm{mg} / \mathrm{g})\end{array}$ \\
\hline 1 & 4 & 15 & 35 & 4.45 \\
\hline 2 & 6 & 15 & 35 & 4.21 \\
\hline 3 & 5 & 15 & 60 & 3.86 \\
\hline 4 & 4 & 45 & 15 & 3.22 \\
\hline 5 & 5 & 45 & 35 & 2.91 \\
\hline 6 & 5 & 15 & 15 & 2.82 \\
\hline 7 & 6 & 45 & 15 & 2.70 \\
\hline 8 & 6 & 45 & 60 & 2.55 \\
\hline 9 & 5 & 75 & 60 & 2.04 \\
\hline 10 & 6 & 75 & 35 & 1.53 \\
\hline
\end{tabular}

\section{Caffeine content determination}

Table 4 and Table 5, demonstrated the use effect of NADES as a solvent (lactic acid-sucrose and citric acid-glucose) with NADESUAE method based on a combination of extraction condition against caffeine content. The 10 highest of caffeine content in beverages extract was obtained in samples using lactic acid-sucrose as a solvent (as can be seen in Table 4) and citric acid-glucose (showed in Table
5). According to the combination factors of extraction condition was obtained the best caffeine content $(4.45 \mathrm{mg} / \mathrm{g}$ sample) with combination factor of $4 \mathrm{~g} / \mathrm{g}$ citric acid-glucose, $15 \mathrm{~mL} / \mathrm{g}$ liquid-solid ratio, and 35 minutes extraction time (in Table 5) and $1.30 \mathrm{mg} / \mathrm{g}$ sample using $2 \mathrm{~g} / \mathrm{g}$ lactic acid-sucrose ratio and $30 \mathrm{~mL} / \mathrm{g}$ liquid-solid ratio for 5 minutes (in Table 4). Figure 1 demonstrated the chromatogram feature for the best value of extract based on difference NADES component used and 
the extraction condition compared with caffeine standard $(1.2 \mu \mathrm{g} / \mathrm{mL})$.

The highest caffeine content $(4.45 \mathrm{mg} / \mathrm{g}$ sample) was obtained using citric acid and glucose with a ratio of $5: 1 \mathrm{~g} / \mathrm{g}$ and the liquid-solid ratio of $15 \mathrm{~mL} / \mathrm{g}$ for 35 minutes. This result was still relatively higher than extraction with roasting $(0.06-2.25 \%$ $\mathrm{mg} / \mathrm{g}$ ) based on the study has been reported by (Hečimović et al.,
2011) and (Belguidoum et al., 2014), while the result was higher than extraction using lactic acid and sucrose with the most top caffeine content of $1.30 \mathrm{mg} / \mathrm{g}$ sample (combination factors of extraction condition such as $2 \mathrm{~g} / \mathrm{g}$ NADES ratio and $30 \mathrm{~mL} / \mathrm{g}$ liquid-solid ratio for 5 minutes).

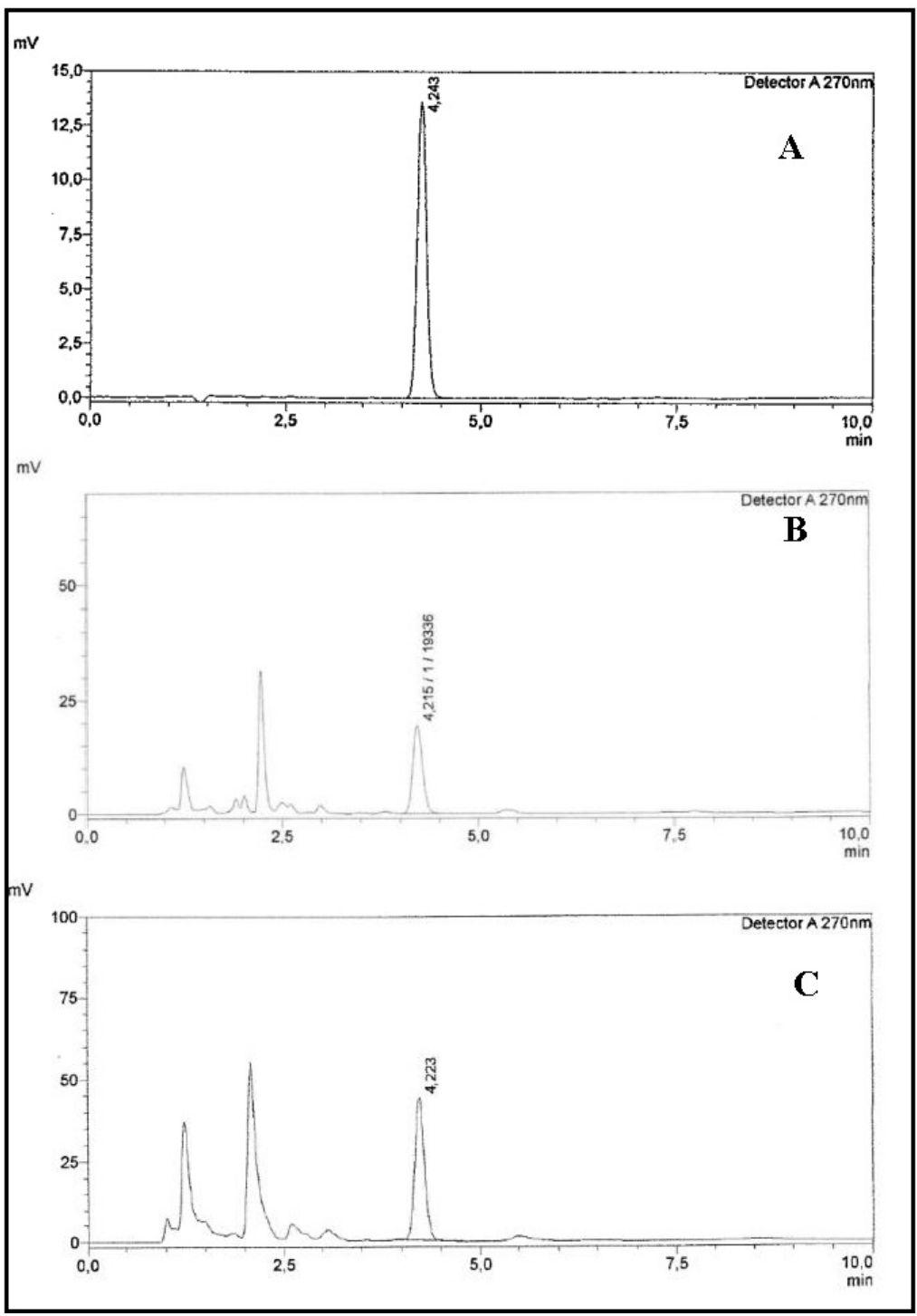

Fig. 1: Chromatogram feature of (A) caffeine standard (1.2 $\mu \mathrm{g} / \mathrm{mL})$, extracts from the solvent of lactic acid-sucrose (B) and citric acid-glucose (C).

Based on the obtained of total polyphenolic and caffeine content demonstrated that the use of different NADES components indicated the specificity of the extracted target compounds and was strongly influenced by some combination of extraction condition. These results were preliminary data for further research that focus on optimization of NADES-UAE method based on various extraction conditions using response surface methodology and aims to obtain an extract with maximum purity of the target compound from the coffee beans.

\section{CONCLUSION}

Based on the above results, the application of NADESUAE method showed the differences specificity of the extracted compounds from coffee beans according to the differences NADES components. The highest total polyphenolic content of $87.01 \mathrm{mg}$ GAE/g sample was obtained using NADES components of $2 \mathrm{~g} / \mathrm{g}$ lactic acid-sucrose ratio and $10 \mathrm{~mL} / \mathrm{g}$ liquid-solid for 5 minutes. While, the highest caffeine content of $4.45 \mathrm{mg} / \mathrm{g}$ was obtained using citric acid-glucose ratio of $5 \mathrm{~g} / \mathrm{g}$, liquid-solid of $15 \mathrm{~mL} / \mathrm{g}$, and extraction time of 35 minutes. These results were preliminary data for further research and obtained the green extraction method with rapid, easy, inexpensive, and environmentally friendly.

\section{ACKNOWLEDGMENT}

This work supported by the Directorate of Research and Community Engagement (DRPM) Universitas Indonesia via 
Hibah PITTA 2018.

\section{CONFLICT OF INTEREST}

All authors have declared no conflict of interest.

\section{REFERENCES}

Ahmad I, Yanuar A, Mulia K, Mun'im A. Extraction of polyphenolic content from Peperomia pellucida (L) Kunth herb with 1-ethyl-3-methylimidazolium bromide as a green solvent. Indian Journal of Pharmaceutical Sciences, 2017a; 79:1013-1017.

Ahmad I, Yanuar A, Mulia K, Mun'im, A. Optimization of ionic liquid-based microwave-assisted extraction of polyphenolic content from Peperomia pellucida (L) Kunth using response surface methodology. Asian Pacific Journal of Tropical Biomedicine, 2017b; 7:pp. 660-665.

Ali MM, Eisa M, Taha MI, Zakaria BA, Elbashir AA. Determination of caffeine in some Sudanese beverages by high performance liquid chromatography. Pakistan Journal of Nutrition, 2012; 11:336-342.

Amorim ACL, Hovell AMC, Pinto AC, Eberlin MN, Arruda NP, Pereira EJ, Bizzo HR, Catharino RR, Filho ZBM., Rezende, C.M. Green and roasted Arabica coffees differentiated by ripeness, process and cup quality via electrospray ionization mass spectrometry fingerprinting. Journal of the Brazilian Chemical Society, 2009; 20:313-321.

Baeza G, Sarria B, Bravo L, Matheos R. Exhaustive qualitative LC-DAD-MS analysis of Arabica green coffee beans: cinnamoyl-glycosides and cinnamoylshikimic acids as new polyphenols in green coffee. Journal of Agricultural and Food Chemistry, 2016; 64:9663-9674.

Belguidoum K, Amira-Guebailia H, Boulmokh Y, Houache, O. HPLC coupled to UV-vis detection for quantitative determination of phenolic compounds and caffeine in different brands of coffee in the Algerian market. Journal of the Taiwan Institute of Chemical Engineers, 2014; 45:1314-1320.

Blum J, Lemaire B, Lafay S. Effect of a green decaffeinated on glycaemia: a pilot prospective clinical study. Nutrafoods, 2007; 6:13-17.

Bobo-García G, Davidov-Pardo G, Arroqui C, Virseda P, MarinArroyo MR, Navarro M. Intra-laboratory validation of microplate methods for total phenolic content and antioxidant activity on polyphenolic extracts, and comparison with conventional spectrophotometric methods. Journal of the Science of Food and Agriculture, 2014; 95:204-209.

Bubalo MC, Ćurko N, Tomašević M, Ganić KK, Redovnikovic IR. Green extraction of grape skin phenolics by using deep eutectic solvents. Food Chemistry, 2016; 200:159-166.

Chemat F, Vian MA. 2014. Green Chemistry and Sustainable Technology: Alternative Solvents for Natural Products Extraction. Heildelberg, New York, Dordrecht, London, Springer, US.

Dai Y, van Spreonsen J, Witkamp GJ, Verpoorte R, Choi YH. Ionic liquids and deep eutectic solvents in natural products research: mixtures of solids as extraction solvents. Journal of Natural Products. 2013.

Dai Y, Witkamp GJ, Verpoorte R, Choi YH. Natural deep eutectic solvents as a new extraction media for phenolic metabolites in Carthamus tinctorius L. Analytical Chemistry, 2013; 85:6272-6278.

Dai Y, Witkamp GJ, Verpoorte R, Choi YH. Tailoring properties of natural deep eutectic solvents with water to facilitate their applications. Food Chemistry, 2015; 187:14-19.

Dai Y, Rozema E, Verpoorte R, Choi YH. Application of natural deep eutectic solvents to the extraction of anthocyanins from Catharanthus roseus with high extractability and stability replacing conventional organic solvents. Journal of Chromatography A, 2016; 1434:50-56.

Fernández MÁ, Espino M, Gomez FJV, Silva MF. Novel approaches mediated by tailor-made green solvents for the extraction of phenolic compounds from agro-food industrial by-products. Food Chemistry, 2017; 239:671-678.
García A, Rodríguez-Juan E, Rodríguez-Gutiérrez G, Rios JJ, Fernández-Bolaños J. Extraction of phenolic compounds from virgin olive oil by deep eutectic solvents (DESs). Food Chemistry, 2016; 197:554-561.

Hečimović I, Belščak-Cvitanović A, Horžić D, Komes D. Comparative study of polyphenols and caffeine in different coffee varieties affected by the degree of roasting. Food Chemistry, 2011; 129:991-1000.

Kerton FM. Alternative Solvents for Green Chemistry. Cambridge: The Royal Society of Chemistry (RSC) Publishing. 2009.

Kozuma K, Tsuchiya S, Kohori J, Hase T, Tokimitsu I. Antihypertensive effect of green coffee bean extract on mildly hypertensive subjects. Hypertension research, 2005; 28:711-718.

Lu W, Alam MA, Pan Y, Wu J, Wang Z, Yuan Z. A new approach of microalgal biomass pretreatment using deep eutectic solvents for enhanced lipid recovery for biodiesel production. Bioresource Technology, 2016; 218:123-128.

Njoroge,JM, Agwanda CO, Kingori PN, Karanja AM, Gathaara MPH. Coffee. in Chopra VL, Peter KV. (Eds) Handbook of Industrial Crops. New York, USA: Haworth Press, pp. 295-333. 2005.

Pan M, Zhao G, Ding C, Wu B, Lian Z, Lian H. Physicochemical transformation of rice straw after pretreatment with a deep eutectic solvent of choline chloride/urea. Carbohydrate Polymers, 2017; 176:307-314.

Pham HNT, Nguyen VT, Vuong QV, Bowyer MC, Scarlett CJ. Bioactive compound yield and antioxidant capacity of Helicteres hirsuta Lour. stem as affected by various solvents and drying methods. Journal of Food Processing and Preservation, 2017; 41:1-9.

Rahardjo P. Panduan Budi Daya dan Pengelolaan Kopi Arabika dan Robusta. Jakarta: Penerbar Swadaya. 2012.

Wang H, Ma X, Cheng Q, Xi X, Zhang L. Deep eutectic solvent-based microwave-assisted extraction of baicalin from Scutellaria baicalensis Georgi. Journal of Chemistry, 2018; 2018:1-10.

Watanabe T, Arai Y, Kusaura T, Okawa W, Kajihara Y, Saito I. The blood pressure-lowering effect and safety of chlorogenic acid from green coffee bean extract in essential hypertension. Journal of Clinical and Experimental Hypertension, 2006; 28:439-449.

Wei Z, Qi X, Li T, Luo M, Wang W, Zu Y, Fu Y. Application of natural deep eutectic solvents for extraction and determination of phenolics in Cajanus cajan leaves by ultra performance liquid chromatography. Separation and Purification Technology, 2015; 149:237-244.

Wei ZF, Wang XQ, Peng X, Wang W, Zhao CJ. Fast and green extraction and separation of main bioactive flavonoids from Radix Scutellariae. Industrial Crops and Products, 2015; 63:175-181.

Xia B, Yan D, Bai Y, Xie J, Cao Y, Liao D, Lin L. Determination of phenolic acids in Prunella vulgaris L.: a safe and green extraction method using alcohol-based deep eutectic solvents. Analytical Methods, 2015; 7:9354-9364.

Xu H, Wang W, Liu X, Yuan F, Gao Y. Antioxidative phenolics obtained from spent coffee grounds (Coffea arabica L.) by subcritical water extraction. Industrial Crops and Products, 2015; 76:946-954.

Zhang X, Li W, Chen W, Kelly DP, Wang X, Zheng K, Du Y. Improvement of near infrared spectroscopic (NIRS) analysis of caffeine in roasted arabica coffee by variable selection method of stability competitive adaptive reweighted sampling (SCARS). Spectrochimica Acta - Part A: Molecular and Biomolecular Spectroscopy, 2013; 114:350-356.

How to cite this article:

Ahmad I, Pertiwi AS, Kembaren YH, Rahman A, Mun'im A. Application of Natural Deep Eutectic Solvent-Based Ultrasonic Assisted Extraction of Total Polyphenolic and Caffeine Content from Coffe Beans (Coffea Beans L.) For Instant Food Products. J App Pharm Sci, 2018; 8(08): 138-143. 